\title{
TEORI APOS DAN IMPLEMENTASINYA DALAM PEMBELAJARAN
}

\section{Mulyono}

Jurusan Matematika FMIPA UNNES

J1. Sekaran Gunungpati Semarang 50229, email: arifahsaptari@ yahoo.co.id

\begin{abstract}
ABSTRAK
Belajar merupakan kerja mental secara aktif. Teori APOS merupakan teori yang mempelajari bagaimana individu belajar konsep matematika. Teori ini mengemukakan bahwa dalam membangun sebuah konsep matematika, individu melalui tahap-tahap aksi, proses, objek, dan skema. Untuk mengetahui bagaimana individu bekerja dan berpikir ketika berada pada tahaptahap itu perlu dilakukan wawancara yang mendalam. Seseorang mungkin bisa berhasil melalui semua tahap tersebut, bisa juga gagal. Meskipun sama-sama berhasil atau sama-sama gagal, antara individu satu dengan yang lainnya, mungkin berbeda aktivitas mental yang dilakukan. Dengan teori ini pengembang pendidikan dapat membuat model pembelajaran yang berorientasi pada teori ini. Teori ini menyediakan langkah-langkah konstruksi konsep matematika, model pembelajaran yang dikembangkan dapat memasukkan langkah-langkah ini ke dalam model yang dibuat pada langkah-langkah pembelajarannya.
\end{abstract}

Kata kunci: Teori APOS, konsep matematika, model pembelajaran

\section{PENDAHULUAN}

Belajar merupakan suatu proses yang bersifat internal pada individu dalam usaha memperoleh berbagai hubungan baru. Pada dasarnya ketika seseorang belajar terjadi proses berpikir, sebab pada saat belajar ia melakukan kegiatan mental. Dalam berpikir itu seseorang menghubungkan antara bagian-bagian informasi yang telah ada dalam pikiran. Pengetahuan yang diperoleh melalui informasi kemudian dihubungkan dengan pengetahuan yang sudah ada, membentuk pengertian baru.

Pembelajaran matematika di sekolah banyak dipengaruhi oleh filsafat konstruktivisme. Konstruktivisme saat ini sangat populer tidak hanya dalam bidang pendidikan, tetapi juga dalam bidang psikologi perkembangan, ilmu sosial, psychology of gender, dan teknologi komputer. Konstruktivisme lahir dari gagasan Piaget dan Vygotsky. Keduanya menekankan bahwa perubahan kognitif hanya terjadi jika konsepsikonsepsi yang telah dipahami sebelumnya diolah melalui suatu proses disequilibrium dalam upaya memahami informasi-informasi baru. Konstruktivisme memandang bahwa pengetahuan merupakan hasil konstruksi kognitif melalui aktivitas seseorang. Menurut pandangan konstruktivisme, pengetahuan perlu dikonstruk atau dibangun sendiri oleh individu yang ingin tahu atau perlu memahaminya.

Bagaimana individu mengkonstruk sebuah konsep matematika? Teori APOS muncul sebagai upaya untuk mempelajari hal ini. Teori ini memperluas ide Piaget tentang abstraksi reflektif. Teori ini mengemukakan bahwa individu mengkonstruksi konsep matematika melalui empat tahap, yaitu: aksi, proses, objek, dan skema. Bagaimana mengimplementasikan teori ini untuk membantu proses pembelajaran? Tulisan ini akan memaparkan kedua hal ini, yaitu 
konstruksi konsep matematika dan pendekatan pembelajaran.

\section{PEMBAHASAN}

Pada bagian ini akan dibahas tentang (1) pembentukan dan perkembangan pengetahuan, (2) konstruksi konsep matematika menurut Teori APOS, dan (3) Implementasi Teori APOS dalam pembelajaran matematika.

\section{Pembentukan dan Perkembangan Pengetahuan}

Pengetahuan manusia itu pada dasarnya adalah aktif. Mengetahui adalah mengasimilasi realitas dalam sistem-sistem transformasi. Mengetahui adalah mentransformasi realitas agar dapat dimengerti bagaimana realitas tertentu itu terbentuk, sehingga pengetahuan bukanlah tiruan pasif atas realitas. Mengetahui sesuatu adalah bertindak atas sesuatu itu, yaitu membentuk sistem transformasi yang dapat menjelaskan hal tersebut. Mengerti realitas adalah membentuk sistem transformasi yang berkaitan dengan realitas tersebut.

Menurut Piaget (dalam Suparno, 1997) semua pengetahuan adalah suatu konstruksi (bentukan) kegiatan/tindakan seseorang. Pengetahuan ilmiah itu berevolusi, berubah dari waktu ke waktu. Pemikiran ilmiah bersifat sementara, tidak statis, dan merupakan proses. Pemikiran ilmiah merupakan proses konstruksi dan reorganisasi yang terus menerus. Pengetahuan bukanlah sesuatu yang ada di luar, melainkan ada di dalam diri seseorang yang membentuknya. Dalam pembentukan pengetahuan, Piaget membedakan tiga macam pengetahuan, yakni: pengetahuan fisis, matematis-logis, dan sosial.

Menurut Piaget (dalam Suparno, 2001) pengetahuan seseorang merupakan abstraksi atas suatu objek atau hal. Piaget membedakan adanya dua macam abstraksi, yaitu: abstraksi sederhana dan abstraksi reflektif.

Abstraksi sederhana adalah abstraksi yang didasarkan pada objek itu sendiri. Dalam abstraksi ini, orang menemukan pengertian sifat-sifat objek itu sendiri secara langsung. Pengetahuan tersebut merupakan abstraksi langsung atas objek itu. Inilah yang juga disebut pengetahuan eksperimental atau empiris.

Abstraksi reflektif adalah abstraksi yang didasarkan pada koordinasi, relasi, operasi, dan penggunaan yang tidak langsung keluar dari sifat-sifat dari objek itu sendiri, tetapi dari tindakan terhadap objek itu. Inilah yang disebut abstraksi logis atau matematis. Misalnya, berhadapan dengan 7 kelereng, seorang anak menghitung kelereng itu sampai 7. Ia menjajarkannya dan menghitungnya, tetap sama 7. Ia meletakkan kelereng di dalam kaleng, dihitung lagi, hasilnya tetap 7 . Ia mengubah-ubah susunan kelereng dan dihitung, hasilnya tetap 7. Anak itu menemukan prinsip komutatif bahwa jumlah kelereng tetap sama meskipun susunannya diubah-ubah. Ia juga menemukan pengertian tentang angka 7 . Sifat tersebut tidak terdapat pada kelereng, tetapi pada aksi terhadap kelereng. 
Pengetahuan ini adalah pengetahuan matematis, bukan fisis.

\section{Konstruksi Konsep Matematika Menurut Teori APOS}

Teori perkembangan kognitif dan teori pengetahuan Piaget cukup banyak mempengaruhi bidang pendidikan, terutama perkembangan pengetahuan pebelajar dan juga bagaimana pebelajar belajar serta bagaimana pengajar membimbing pebelajar belajar. Piaget adalah seorang peneliti yang sangat berpengaruh dalam bidang psikologi perkembangan selama abad ke-20. Menurut Piaget, teori psikologi dapat menggunakan konsep biologi, bahwa intelegensi dapat dilihat sebagai suatu adaptasi organisme terhadap lingkungannya. Tingkah laku untuk beradaptasi dengan lingkungan selalu dikontrol oleh organisasi mental yang disebut skema. Seorang individu akan mengkonstruk skema baru dengan menggunakan abstraksi reflektif. Dubinsky, dkk (2000) mengadaptasi ide Piaget menjadi teori perkembangan skema seseorang yang berpusat pada berpikir secara matematis, berupa kerangka APOS (Aksi-Proses-ObjekSkema).

Teori APOS hadir diawali dengan hipotesis bahwa pengetahuan matematika terkandung dalam kecenderungan individu berkaitan dengan situasi permasalahan matematika yang dihadapi dengan mengkonstruk aksi, proses, dan objek mental dan mengorganisasikan mereka ini dalam skema untuk memahami situasi itu dan memecahkan masalah tersebut. Konstruksikonstruksi mental ini disebut Teori APOS. Ide ini muncul dari usaha untuk mengembangkan karya Piaget pada abstraksi reflektif dalam pembelajaran anak-anak ke level pembelajaran matematika perguruan tinggi. Teori APOS ini muncul sebagai usaha untuk memahami mekanisme dari abstraksi reflektif yang diperkenalkan oleh Piaget untuk menggambarkan perkembangan berpikir logis pada anak-anak, dan mengembangkan ide ini ke konsep matematika yang lebih lanjut.

Menurut Dubinsky (2000) karakteristikkarakteristik yang harus dimiliki oleh suatu teori pembelajaran adalah sebagai berikut.

1) Mendukung prediksi.

2) Memiliki kemampuan untuk menjelaskan.

3) Dapat diterapkan pada jangkauan fenomena yang luas.

4) Membantu mengorganisaskani pemikiran tentang fenomena-fenomena belajar.

5) Sebagai alat untuk menganalisis data.

6) Menyediakan bahasa untuk mengkomunikasikan tentang pembelajaran.

Dubinsky, dkk (2000) mengemukakan bahwa teori APOS adalah teori konstruktivis yang mempelajari bagaimana belajar konsep matematika. Teori ini didasarkan pada hipotesis tentang sifat pengetahuan matematika dan bagaimana pengetahuan matematika yang berikut ini.

An individual's mathematical knowledge is her or his tendency to respond to perceived mathematical problem situations and their solutions by reflecting on them in a social context and constructing or reconstructing mathematical actions, processes and 
objects and organising these in schemas to use in dealing with the situations.

Teori APOS adalah elaborasi tentang konstruksi mental dari aksi, proses, objek, dan skema. Menurut Dubinsky, kerangka kerja teori APOS dalam mengkonstruk konsep matematika adalah sebagai berikut.

An action is transformation of an object which is perceived by the individual as being external. The transformation is carried out by reacting to external cues that give precise details on what steps to take. When an action is repeated, and the individual reflects upon it, it may be interiorized into a process. That is, an internal construction is made that performs the same action, but now not necessarily directed by external stimuli. When an individual reflects on actions applied to a particular process, became aware of the process as a totality, realizes that transformations (whether they be actions or process) can act on it, and is able to actually construct such transformations, then we say the individual has reconstructed this process as a cognitive object. A schema for a certain piece of mathematics is an individual's collection of actions, processes, objects, and other schema which are linked consciously on unconsciously in a coherent framework in the individual's mind and may be brought to bear upon a problem situation involving that area of mathematics.

Menurut teori APOS, aksi merupakan suatu aktivitas berupa pengulangan fisik atau manipulasi mental yang mendasarkan pada beberapa algoritma secara eksplisit. Aksi ini merupakan reaksi dari rangsangan yang subjek terima dari eksternal. Aksi dapat dimaksudkan sebagai transformasi fisik atau mental dari objek untuk memperoleh objek lain. Apabila aksi dilakukan secara berulang, dan dilakukan refleksi atas aksi itu, maka aksi-aksi tersebut diinteriorisasi menjadi proses, yaitu suatu konstruksi internal yang dilakukan pada aksi yang sama tetapi sekarang tidak perlu langsung dari rangsangan eksternal. Individu dapat mengkonstruk objek kognitif dengan dua cara. Pertama, jika seorang individu merefleksi aksi yang diterapkan untuk proses tertentu, dan sadar bahwa proses sebagai totalitas, ternyata bahwa transformasi (apakah aksi atau proses) dapat dilakukan dan dapat dikonstruk secara aktual sebagai transformasi, maka individu tersebut melakukan rekonstruksi proses ini sebagai objek kognitif. Pada kasus ini, dikatakan bahwa proses di-enkapsulasi (encapsulated) menjadi objek. Kedua, untuk mengkonstruk suatu objek kognitif, seorang individu melakukan refleksi pada suatu skema tertentu dan sadar bahwa skema tersebut sebagai totalitas serta dapat melakukan aksi padanya. Pada kasus ini, dikatakan bahwa individu men-tematisasi (thematized) skema menjadi objek. Skema untuk potongan matematika tertentu adalah koleksi individu atas aksi, proses, objek, dan skema lain yang dikaitkan dalam kerangka kerja pada pikiran individu dalam menghadapi suatu problem matematika.

$$
\text { Karakteristik-karakteristik teori }
$$
pembelajaran yang telah disebutkan di atas dikembangkan pada Teori APOS. Teori APOS memenuhi enam karakteristik dari teori pembelajaran yang dikemukakan oleh Dubinsky di atas, yaitu: 
1) Mendukung prediksi. Kemampuan prediktif dari teori APOS berada pada pernyataan yang tegas, yaitu bila siswa membuat konstruksi mental tertentu, maka ia akan belajar topik matematika tertentu.

2) Memiliki kemampuan untuk menjelaskan. Teori APOS dapat digunakan untuk mendiskripsikan transkrip interview dalam rincian yang sangat baik. Teori APOS dapat juga digunakan untuk mencoba menemukan ide-ide matematika dan kemungkinan yang ada berupa performa siswa. Kemudian mencoba menemukan penjelasan dari perbedaan dalam pengertian mengkonstruksi atau tidak mengkonstruksi aksi tertentu, proses, objek dan/ atau skema. Teori APOS berupaya menjelaskan tentang keberhasilan dan kegagalan siswa.

3) Dapat diterapkan pada jangkauan fenomena yang luas. Teori APOS dapat diterapkan oleh pengembangnya dan juga oleh orang lain, untuk sejumlah topik matematika.

4) Membantu mengorganisasikan pemikiran tentang fenomena-fenomena belajar. Teori APOS dapat digunakan untuk mengembangkan suatu dekomposisi genetik dari suatu konsep matematika sebagai satu cara mengorganisasikan pikiran seseorang tentang bagaimana ia dapat belajar tentang konsep tertentu.
5) Sebagai alat untuk menganalisis data. Suatu metode yang sangat khusus dalam menggunakan teori APOS untuk menganalisis data seperti yang telah disebutkan pada no. 2 di atas.

6) Menyediakan bahasa untuk mengkomunikasikan tentang pembelajaran. Istilah-istilah seperti aksi, proses, objek, skema, interiorisasi dan enkapsulasi sekarang secara umum digunakan dalam pembelajaran matematika.

\section{Implementasi Teori APOS dalam Pembelajaran Matematika}

Dalam tulisan ini akan dipaparkan implementasi teori APOS dalam pembelajaran matematika. Penulis melihat dari dua hal, yaitu: (a) perkembangan skema individu dan (b) pendekatan pembelajaran berdasarkan Teori APOS.

\section{Perkembangan Skema Individu}

Menurut Dubinsky (2000), pemahaman terhadap suatu konsep matematika merupakan hasil konstruksi atau rekonstruksi terhadap objek-objek matematika. Konstruksi atau rekonstruksi itu dilakukan melalui aktivitas aksi-aksi, proses-proses, dan objek-objek matematika yang diorganisasikan dalam suatu skema untuk memecahkan masalah matematika. Hal ini dapat dianalisis melalui suatu analisis dekomposisi genetik (genetic decomposition) sebagai operasionalisasi dari Teori APOS (Action, Process, Object, dan Schema). Hasil analisis dekomposisi genetik 
ini adalah suatu penjelasan dari aksi, objek, proses, skema, dan relasi-relasinya yang individu miliki untuk konsep ini. Dari sini dapat diketahui pemahaman individu yang berusaha membangun pemahamannya tentang konsep-konsep matematika. Teori APOS merupakan teori konstruktivis tentang bagaimana terjadinya/berlangsungnya belajar suatu konsep atau prinsip matematika, yang dapat digunakan sebagai suatu elaborasi tentang konstruksi mental dari aksi, proses, objek, dan skema. Teori ini dapat digunakan sebagai alat analisis untuk mendeskripsikan perkembangan skema seseorang pada suatu topik matematika yang merupakan totalitas dari pengetahuan yang terkait terhadap objek tersebut. Perkembangan skema merupakan suatu proses yang dinamis dan selalu berubah.

Untuk melihat perkembangan skema individu berdasarkan teori APOS terhadap konsep matematika yang dipelajari perlu diturunkan karakteristik dari definisi konstruksi-konstruksi mental yang dikemukakan oleh Dubinsky di atas. Di sini penulis menurunkan karakteristik dari aksi, proses, objek, dan skema sebagai berikut.

(i). Berdasarkan definisi Aksi, penulis menurunkan karakteristik dari Aksi adalah sebagai berikut.

1) Hanya menerapkan rumus atau langsung menggunakan rumus yang diberikan.

2) Hanya menerapkan algoritma yang sudah ada.
3) Hanya mengikuti contoh yang sudah ada sebelumnya.

4) Memerlukan langkah-langkah yang rinci untuk melakukan transformasi.

5) Kinerja dalam aksi berupa kegiatan prosedural.

(ii). Berdasarkan definisi Proses, penulis menurunkan karakteristik dari Proses adalah sebagai berikut.

1) Untuk melakukan transformasi tidak perlu diarahkan dari rangsangan eksternal.

2) Bisa merefleksikan langkah-langkah transformasi tanpa melakukan langkahlangkah itu secara nyata.

3) Bisa menjelaskan langkah-langkah transformasi tanpa melakukan langkahlangkah itu secara nyata.

4) Bisa membalik langkah-langkah transformasi tanpa melakukan langkahlangkah itu secara nyata.

5) Sebuah proses dirasakan oleh individu sebagai hal yang internal, dan di bawah kontrol individu tersebut.

6) Proses itu merupakan pemahaman prosedural.

7) Belum paham secara konseptual.

(iii). Berdasarkan definisi Objek, penulis menurunkan karakteristik dari Objek adalah sebagai berikut.

1) Dapat melakukan aksi-aksi pada objek.

2) Dapat men-dekapsulasi suatu objek kembali menjadi proses dari mana objek itu berasal atau mengurai sebuah skema 
yang ditematisasi menjadi berbagai komponennya.

3) Objek merupakan suatu pemahaman konseptual.

4) Dapat menentukan sifat-sifat suatu konsep.

(iv). Berdasarkan definisi Skema, penulis menurunkan karakteristik dari Skema adalah sebagai berikut.

1) Dapat menghubungkan aksi, proses, dan objek suatu konsep dengan konsep lainnya.

2) Dapat menghubungkan (menginterkoneksikan) objek-objek dan prosesproses dengan bermacam-macam cara.

3) Memahami hubungan-hubungan antara antara aksi, proses, objek, dan sifat-sifat lain yang telah dipahaminya.

4) Memahami berbagai aturan/rumus yang perlu dilibatkan/digunakan.

Berdasarkan karakteristik yang diturunkan penulis ini, perkembangan skema individu dapat dieksplorasi. Bagaimana individu bekerja ketika berada dalam tahaptahap konstruksi yang dikemukakan dalam teori APOS dapat ditelusuri. Seseorang yang sedang belajar sebuah konsep matematika mungkin bisa berhasil melewati semua tahap, atau gagal. Dan yang tak kalah penting untuk diungkap adalah bagaimana individu berpikir ketika berada dalam tahap-tahap tersebut. Mungkin saja individu yang satu dengan yang lainnya berbeda cara berpikirnya dalam tahap-tahap dari APOS tersebut. Untuk bisa mengungkap hal ini perlu dilakukan penggalian data dengan wawancara yang mendalam.

\section{Pendekatan Pembelajaran Berdasarkan} Teori APOS

Dubinsky, dkk (dalam DeVries, 2001) mengemukakan suatu pendekatan pembelajaran berdasarkan teori APOS yang dinamakan sikel pembelajaran ACE. Sikel pembelajaran ini meliputi: (1) Activity (A), yang melibatkan kerja dengan komputer dengan bahasa pemrograman yang interaktif; (2) Class discussion (C), yang memerlukan adanya belajar kooperatif, dan (3) Exercise (E), adanya latihan untuk mengokohkan atau memperkuat konsep-konsep yang dikonstruksi.

Walaupun Dubinsky telah memberikan suatu pendekatan pembejalaran berdasarkan teori APOS ini, penulis berpendapat masih terbuka bagi para pengembang pendidikan untuk mengembangkan model pembelajaran yang melibatkan teori APOS ini. Model pembelajaran yang dikembangkan bisa menggunakan langkah-langkah APOS ketika siswa/mahasiswa mengkonstruk sebuah konsep matematika.

Ada dua hal yang dipandang sebagai karakteristik pembelajaran berdasarkan teori APOS, yaitu pembelajarannya meliputi: (i) konstruksi-konstruksi mental dalam memahami suatu konsep matematika dan menggunakan siklus ACE. Berikut ini adalah deskripsi untuk siklus pembelajaran ACE tersebut.

\section{(1) Aktivitas (activity)}


Kegiatan mahasiswa di laboratorium komputer menggunakan pemrograman yang interaktif. Dubinsky dan kawan-kawan menggunakan ISETL (interactive SET language) yaitu bahasa pemrograman yang dirancang untuk pembelajaran matematika dalam mengerjakan tugas-tugas pemrograman secara berkelompok. Kegiatan ini bertujuan untuk membantu konstruksi mental: aksi, proses, objek, dan skema. Kegiatan ini lebih ditekankan pada upaya untuk memberikan mahasiswa suatu pengalaman daripada meminta mereka untuk memberikan jawaban yang benar. Melalui kegiatan ini mahasiswa memperoleh pengalaman yang berhubungan dengan isu-isu matematika yang akan dikembangkan di dalam perkuliahan. Pengalaman yang mahasiswa peroleh selama di laboratorium komputer akan merupakan bekal bagi mahasiswa yang bersangkutan agar dapat berperan aktif dalam diskusi kelas. Dengan berbekal pengalaman dari laboratorium komputer, konsep-konsep abstrak yang akan didiskusikan di kelas tidak sepenuhnya asing bagi mahasiswa, melainkan dianggap sebagai suatu elaborasi terhadap pengalaman yang sudah dimiliki sebelumnya.

\section{(2) Diskusi Kelas (class discussion)}

Kegiatan di dalam kelas di mana mereka bekerja berkelompok diisi dengan kegiatan berupa pengerjaan tugas-tugas yang masih berhubungan dengan kegiatan yang telah diberikan di laboratorium komputer. Keterlibatan dosen dalam diskusi pada masingmasing kelompok dimaksudkan untuk memberi kesempatan kepada mahasiswa untuk melakukan refleksi pada apa yang sudah mereka kerjakan di laboratorium dan pada tugas yang sedang mereka kerjakan. Dalam diskusi kelas, dosen memberikan definisi, penjelasan, dan tinjauan untuk mengaitkan dengan apa-apa yang mahasiswa telah pikirkan.

\section{(3) Latihan (exercise)}

Pada siklus ini mahasiswa diberikan latihan-latihan soal untuk dikerjakan secara berkelompok. Latihan-latihan ini diharapkan dikerjakan di luar kegiatan kelas dan laboratorium dan dapat berupa pekerjaan rumah. Tujuan dari latihan-latihan ini adalah untuk mengokohkan/memberi penguatan konsep-konsep matematika yang telah dikonstruksi, menerapkan konsep-konsep yang sudah dipelajari, dan mengajak mahasiswa berpikir tentang hal-hal yang akan dipelajari pada pertemuan berikutnya.

\section{PENUTUP}

Perkembangan skema individu dalam konstruksi mental aksi, proses, objek, dan skema dapat ditelusuri melalui wawancara yang mendalam. Berdasarkan hasil analisis data dari wawancara yang mendalam dapat diketahui bagaimana individu berpikir ketika berada pada tahap-tahap konstruksi menurut teori APOS. Untuk membantu proses pembelajaran untuk mencapai konstruksi-konstruksi itu dan memperkokoh konstruksi yang sudah dibangun, diberikan suatu pendekatan pembelajaran yang disebut sikel pembelajaran ACE. Sikel pembelajaran ACE ini melibatkan belajar 
kelompok, penggunaan komputer dengan bahasa pemrograman yang interaktif, dan latihan. Teori APOS dapat dijadikan dasar dalam pengembangan sebuah model pembelajaran matematika.

\section{DAFTAR PUSTAKA}

DeVries, David J. 2001. RUMEC/APOS Theory Glossary. http: //www.cs.gsu.edu/ $\sim$ rumec/glossary. Didownload pada tanggal 16 Juni 2009.

Dubinsky. 2000. Using a Theory of Learning in College Mathematics Courses. http: //ltsn.mathstore.ac.uk/newsletter/may2001/ pdf/learning.pdf. Didownload pada tanggal 16 Juni 2009.

Dubinsky, dan Fauvel, J. 2000. Teaching and Learning Undergraduate Mathematics. http://www.bham.ac.uk/ctimath/talum12.ht m. Didownload pada tanggal 16 Juni 2009.

Soedjadi, R. 2000. Kiat Pendidikan Matematika di Indonesia: Konstatasi Keadaan Masa Kini Menuju Harapan Masa Depan. Jakarta: Dirjen Dikti.

Soedjadi, R. 2007. Masalah Kontekstual Sebagai Batu Sendi Matematika Sekolah. Surabaya: Pusat Sains dan Matematika Sekolah (PSMS) Unesa.

Suparno, Paul. 1997. Filsafat Konstruktivisme dalam Pendidikan. Yogyakarta: Kanisius.

Suparno, Paul. 2001. Teori Perkembangan Kognitif Jean Piaget. Yogyakarta: Kanisius. 